\title{
Interview via e-mail by the Scientific Editor with Elizabeth Orna upon the publication of her latest book, Information strategy in practice
}

\author{
Liz Orna is a member of the Editorial Board of the South African Journal of Information \\ Management. \\ PvB: \\ Congratulations with your latest book! Before we discuss it in more detail, please tell us \\ more of yourself, for example where did you acquire your academic qualifications, who are \\ your previous employees, what is the nature of your work, and so forth.
}

EO:

The most interesting and enjoyable bits of my academic education have been those added in conjunction with my working life and arising from the nature of the job.

I started by reading English at University College London, where I also did my MA. First paid work was as a free-lance proof-reader and indexer and, looking back, I now realise that contact with publishing, and getting hooked on indexing, provided the key to most of what I've done since.

I went on to work as a technical book editor for George Newnes and Wiley, and then became editor of an education journal for The Association of Teachers in Technical Institutions (now The National Association of Teachers in Further and Higher Education). The job title there was Information Officer, so I set about developing an information service, drawing on nothing more than my experience of indexing! Editing the journal brought me into contact with another new field that became important in my work and ideas - typographic design through working with the designer who won a competition for re-designing the magazine. (He has been a valued colleague ever since, and has designed all the books I have written.)

That combination of activities set the pattern for the next job, with responsibility for setting up an information service and managing a research publishing programme, at the Engineering Industry Training Board. By that time I had decided that even if my employers didn't see the need for qualification in what they were paying me to do, I certainly did, and as their business in life was training I convinced them that they should support me in getting professionally trained. They agreed I could do a Diploma in Librarianship at UCL by parttime study, and a busy and rewarding two years followed. It was my good fortune that I chose the scientific information option on the course, which was run by B.C. Brookes, who encouraged thinking and became a friend and mentor for the rest of his life.

Over the next few years at the EITB, my ideas about what I wanted to do gradually took shape. I knew that the next move was to an independent existence where I could put the 
rather unusual combination of skills I'd acquired by chance to use in a new and integrated way that would serve the cause of both the management of information and its presentation to users. In 1979 I became an independent information consultant, with those specialisms, and that's what I've continued to do ever since, combined with teaching as a visiting lecturer in the UK and elsewhere, and writing.

I added the final bit of my academic education in the 1990s, when I finally felt mature enough to do doctoral research - on how organizations manage their information products. That allowed me to draw on both sides of my life's experience, and to develop the case for bringing information products and their presentation within the scope of information management.

PvB:

You have many years' experience in the information management fields. What are your current (work-related) involvements as a consultant, that is, in which areas do you to work and consult?

EO:

So far as information consultancy is concerned, I've worked in two main areas: thesaurus construction (a development of my interest in indexing) came first, at a time when terminology control was much pursued (it's been interesting to see the subject re-discovered in the context of meta-data and taxonomy!). After publication of the first edition of Practical information policies in 1990, I became involved in giving courses on developing organizational information policies, and on information auditing, and that led to assignments in those areas. Recent consultancy work on information auditing has often arisen from a commitment on the part of the organizations involved to move towards knowledge management (for which some are better equipped than others), and I've been able to take part in extending the scope of information auditing to a range of interesting areas.

The editorial consultancy work is for clients who want to ensure that information products which play a critical role in their work are presented in a way which is appropriate for the content, the users and the ways in which the products will be used. Some assignments involve conceptual structure, and both verbal and the visual presentation - and on these I work in collaboration with information designers. In other cases, particularly where the products will be presented in digital form, I am commissioned to advise on structure and wording. Usually I do the writing, but sometimes I'm called on to be a 'quality assurance editor' on work created by other originators. I did that recently for a 'model information policy' to be issued in the local government area, in the context of customer relations management (CRM).

PvB:

In the UK, and as a consultant, you obviously find your work very stimulating. How would you rate the status of information management in the UK today?

EO:

So far as the UK is concerned, status is variable in my experience. It really seems to depend on how much understanding TOTO (Top Of The Organization - the more or less affectionate way in which staff in one business of my acquaintance refer to senior management) has of the concept of information, and of what the organization needs to do with it.

I've worked with organizations that have a core of experienced information managers who are highly regarded, work in strong alliances with systems and IT professionals, understand the organization's structure and culture, and are able to contribute authoritatively to business strategy development. I've worked with others, which employ well-qualified information 
managers, but don't know how to use them and give them little opportunity to exercise their skills. I've come across others again that think a commitment to knowledge management means information management is no longer needed. And on occasion I've met organizations whose whole business is centred on promoting and managing exchanges of knowledge and information, but which lack any core group of professional information managers with coordinating responsibility.

Case studies for the book I'm currently writing have re-dressed the balance by providing examples of organizations that, over the years, have come to understand that most of their staff need to manage some information as part of their job, and that they need a strong group of professionals to support these 'incidental information managers' in that element of their work.

PvB:

Nobody can predict the future, but how do you see how the future of information management should enfold, or in other words, the new developments or trends that should or might develop in the near future?

EO:

I'd like to see it developing in the way implied by some of my observations above:

- Recognition that information management is an essential part of many jobs, and that a central core of professional information managers is required to co-ordinate and support the 'incidental information managers'.

- An 'internal consultancy' role for information managers, with their input being sought as a matter of course on planned developments of business strategy, new directions and innovations.

- More cross-disciplinary alliances between people professionally concerned with information in various ways: not just librarians/information managers and IS/IT specialists - which I'm glad to say is happening to an increasing extent, but also human resources and training, corporate communications, and designers of the organization's information products, both electronic and paper-based (that's because I'm convinced that the concerns of information management should extend to the products which are the point where users meet information).

PvB:

Now back to your new book. First of all, you have written at least two previous books, Information management in museums (with Charles Pettitt, Gower 1998) and Practical information policies (Gower 1999). Why do you need (tend) to write books, and not concentrate on articles in scholarly journals. Why are writing books important to you?

EO:

I started writing books almost by accident, once I had become self-employed and had more control over how I spent my time. It hadn't been an ambition before, but having written one I found I liked the whole process of doing it. Not sure whether it's a psychological need; in part it's certainly a wish to give something in return for all the things I've gained from working with other people, from reading, and from exchanging ideas with friends and colleagues. The books are always practical, in the sense that I want them to help readers to do or to understand something that they have to do, or wish to do, in the course of their work. At the same time I don't want just to tell them 'here's how you do such and such'; I like offering the ideas that underlie the practice I propose.

As to why I don't concentrate on articles in scholarly journals - well, I'm not an academic, I'm just a visitor to academic institutions and have never had ambitions to be more than that. 
So I'm not under any pressure to produce articles, and have only done it when I've felt like it or been invited. It's a more constrained way of writing, whereas in books I feel free to write more or less as I talk - with the added advantage that there's time to be a bit more eloquent and work out ideas more fully than I can when talking.

I really like developing the structure of a book, so that the end product is like a good building that makes visitors welcome and is pleasant to walk about in. From that point of view, it has always been an education and a pleasure to work with the typographic designer, Graham Stevens, and to see how he gives visual expression to the structure through typography which enriches the written words, and graphics which complement them, how he turns to advantage all the constraints that the process of publication imposes.

PvB:

What were the messages conveyed in (or the essence of) these two earlier books? They were published only about one year apart, but their titles seem very much apart!

EO:

I don't seem to manage the division of my time between writing and more profitable work very well, do I? It's even worse than just those two books; in the period beginning about 1994 when I was writing them, I also wrote my doctoral thesis - I must indeed be fond of a treat as they say!

The two books aren't really that far apart in subject matter or intention. They both make the argument that any kind of organization needs to think about:

- What constitutes 'information' in the light of whatever it's in business to do, and of what it needs to know in order to stay in business, survive and prosper;

- how it needs to use the information, and how people need to interact in making use of it;

- and, in the light of that, to develop a clear policy for what it does with information, which will form the basis for how it collects and manages the stuff; and

- they both suggest ways of setting about all that, and give examples in the form of case studies of actual organizations.

The only difference lies in the fact that Information management in museums looks at the ideas in relation to a specific type of organization, while Practical information policies relates to any kind.

As to the concern with museums, I should explain that I've been hooked on them from early childhood. The very first book I wrote, which appeared in 1980, was about Handling information in museums. It came about because, while I was studying librarianship and information science, I started wondering whether museums did the sort of things that libraries did, and whether they did them in the same way. So I began cultivating the acquaintance of curators, going behind the scenes to museum offices and workrooms, and asking questions, the answers to which astonished and intrigued me. That was the time when some museum people were getting interested in computers, and I got to know the staff of what became the Museum Documentation Association. It seemed to me that they didn't know what they ought about indexing, and I told them so. They didn't show me the door; instead, very tolerantly, they invited me to run a workshop for some interested curators; and it was putting together material for that which gave me the incentive to send a proposal for a book to the publisher Clive Bingley. He invited me for a talk, and handed me a contract at the end of it. That book was the fore-runner of Information management in museums, on which I had the pleasure of working with my original co-author, the museum curator Charles Pettitt, once again. 
PvB:

Your other publications, for example journal articles, were they also representative of the consulting work you are doing? Name some of the topics (subjects) covered by a few of your articles?

EO:

Yes, they've been on the subjects that I've had occasion to think about in the course of work, as this selection of titles indicates:

- Liveware or real people? (using human resources in information handling)

- Information management in museums; here's more to it than documentation and computers

- Intelligent information policies

- Information design and information science: a new alliance?

- Information design and information services

- Managing information products

- Using knowledge and information to manage and master change

- Foundations for knowledge management

- The human face of information auditing

- People and technology: battlefield or creative interaction

- Information products and presentation in organizations: accident or design?

- Information products revisited

- How organizations use information

- The knowing museum.

PvB:

Your latest book (Information strategy in practice, Gower, 2004) again conveys fascinating lessons learned from your own consultancy experience. First, what is your definition of an information strategy and why should organizations develop and implement such a strategy?

EO:

I define it in the book in this way:

'Information strategy is the detailed expression of information policy in terms of objectives, targets, and actions to achieve them, for a defined period ahead. Information strategy provides the framework for the management of information. Information strategy, contained within the framework of an organizational policy for information and supported by appropriate systems and technology, is the "engine" for:

- Maintaining, managing and applying the organization's information resources

- Supporting its essential knowledge base and all who contribute to it, with strategic intelligence, for achieving its key business objectives.'

I think the terms of the definition make it clear why organizations need a strategy for what they do with information. If they're using information in line with whatever they're in business to do, they're more likely to perform well. And from the point of view of selfpreservation for information managers, an information strategy derived from overall business objectives and strategy is a useful thing to have about the place.

PvB:

And how do you see the correlation and/or integration between an organization's business strategy and its information strategy?

EO:

See above. I also think my ideas on this are close to the concept of 'information orientation' 
advanced, on the basis of research, by Marchand and his colleagues - the alignment and constructive interaction of information management, information technology and information behaviour in support of business strategy, which appears to be a condition for getting full value from information as expressed in business performance.

PvB:

Information strategy in practice is obviously aimed at information professionals working in the information industry. How should one use the book: as a textbook to read from beginning to end, or rather a type of manual, to consult a specific chapter or section when the need arises?

EO:

Well, not primarily ... Practical information policies was specifically written for working information professionals. This one draws on the core of that book, but is actually designed for three groups of readers; the first of whom consists of students preparing to enter any of the information professions. I originally wanted the publishers to do a paperback edition of PIP for students, and this is the next best thing. I'd guess many of them would want to read it as a textbook, and then perhaps refer back to specific topics in relation to what they're doing at various points in their courses.

The second group is 'incidental information managers': people whose main work is something else though containing an element of information management - I know from experience that they need and want help.

And the final group consists of managers who haven't an information background, but who are line managers of information professionals, or have oversight of information-related projects. Again, consultancy experience has shown that, while some may not realise it, they really need help in understanding what information managers know and are capable of doing (sometimes, when faced with particularly crass line managers, I suspect they are just about capable of grievous bodily harm!)

PvB:

What is new in the book, in other words, where lies its contribution to the current information management literature?

EO:

I think the distinctive contribution lies in:

- The 'Practical Insights' based on actual recent experience, which follow the accounts of such processes as information auditing and developing an information strategy. I've found, in running courses for information professionals, and in consultancy, that people want real-life examples of successful ways of doing what's recommended rather than being left on their own when it gets to that point.

- The practical advice given in the final chapter, again on the basis of experience, on dealing with typical problems that arise to confront information professionals when they embark on these processes.

The 'Ideas and Arguments' brought together in Chapter 7 about topics of current interest and permanent importance, including:

- Integrating information, IT and human interactions;

- taxonomy;

- technological and human support for information interactions among people;

- the value of knowledge and information to organizations and how to measure it; 
- applying knowledge and information to meeting and initiating change; and

- how knowledge management and information management are related, why organizations need both, and how they should be integrated.

PvB:

You have a very busy schedule as an information management consultant. When do you get the time to write (or do you write during office hours)?

EO:

As far as possible I try to avoid doing them in the same period of time, because they're not compatible activities! If I'm working on a major consulting assignment, I can't give proper time to writing, and vice versa. So when I'm writing a book, I try to keep consultancy assignments and other work at a manageable level, and when I'm doing a lot of consultancy, I don't attempt to write.

When I'm working on a book, every so often I take a week away in some quiet place, and do nothing but write. All my books embody case studies, which give me a rather different kind of insight from what one gets from consultancy; I'm an 'organization fancier' and enjoy the opportunity of going into organizations and asking questions without being under any obligation other than giving an honest account in what I write. Over the years, doing this has helped me build up a large network of good contacts, and provided useful examples to draw on in lots of contexts.

PvB:

A major milestone was reached with Information strategy in practice. What are your future plans? Are you thinking of writing more? If so, tell us about your plans (or are they still confidential)?

EO:

Yes, I'm just about to go to Wales for a week's writing on the new book: Making knowledge visible. This one is very close to my heart, because it brings together all the strands that have engaged me during my working life. I explored the main themes in the course of my doctoral research on how organizations manage their information products, but this won't be the Big Boring Book of the thesis. I'm writing something practical, with many stories from real life, to help organizations that want to get maximum value from their information products.

The essential argument of the book is:

'No business without Information Products', because:

Knowledge lives invisible inside human minds, and is made visible, communicated and exchanged only when people:

- Transform it into information

- Put it into information products.

Information products are:

- Knowledge made visible

- Information resources

- The meeting place between users and information

- What information management manages

The vehicle by which information gets around inside organizations and between them and their 'outside world' of customers, clients, members, etc. 
So they should be recognized as essential elements in:

- Information strategy

- Information architecture

- Business processes.

And:

Their creation, management and use need the combined support of:

- Knowledge and information management

- Information systems and technology tools

- Information design.

Liz, thanks very much for your time!

Pieter A. van Brakel

Scientific Editor

Comments on the above can be sent to:

Pieter van Brakel

Editor

pavb@rau.ac.za

Disclaimer

Articles published in SAJIM are the opinions of the authors and do not necessarily reflect the opinion of the Editor, Board, Publisher, Webmaster or the Rand Afrikaans University. The user hereby waives any claim he/she/they may have or acquire against the publisher, its suppliers, licensees and sub licensees and indemnifies all said persons from any claims, lawsuits, proceedings, costs, special, incidental, consequential or indirect damages, including damages for loss of profits, loss of business or downtime arising out of or relating to the user's use of the Website. 
ISSN 1560-683X

Published by InterWord Communications for the Centre for Research in Web-based Applications, Rand Afrikaans University 